\title{
Immunomodulation of helicobacter infection
}

\author{
Ken Croitoru MD FRCPC
}

\begin{abstract}
K Croitoru. Immunomodulation of helicobacter infection. Can J Gastroenterol 1999;13(3):237-241. Helicobacter pylori leads to a chronic infection in humans that is associated with gastric inflammation and a vigorous immune response. Despite the humoral and cellular responses that can be detected in both human and animal models of helicobacter infection, the immune response fails to eliminate the organism. Eradication failure may be due to the niche in which $H$ pylori confines itself, well away from direct contact with elements of the immune system. Alternatively, the general tendency of the intestinal immune response to downregulate reactivity to noninvasive luminal bacteria also may contribute to the failure to eliminate helicobacter infection. Results of vaccine studies in mouse models indicate that modulating the helper T cell response from a T helper cell type 1 to a T helper cell type 2 response likely is required for the prevention and elimination of helicobacter infection. Understanding the mechanisms by which the immune response controls bacterial infections will allow for the design of novel strategies of immune modulation and the development of vaccines for both the treatment and prevention of $H$ pylori.
\end{abstract}

Key Words: Helicobacter pylori, Immune response, $T$ cell

\section{Immunomodulation de l'infection à Helicobacter}

RÉSUMÉ : Helicobacter pylori provoque chez l'être humain une infection chronique qui est associée à une infection gastrique et à une réponse immunitaire vigoureuse. Malgré les réponses tumorales et cellulaires qui peuvent être décelées, tant chez l'être humain que chez les animaux de laboratoire, en présence d'une infection à $H$. pylori, la réponse immunitaire échoue à éliminer l'organisme pathogène. L'échec de l'éradication pourrait être attribuable à la niche dans laquelle se confine $H$. pylori, bien à l'abri de tout contact direct avec les éléments du système immunitaire. D'autres croient que la tendance générale de la réponse immunitaire intestinale à régler à la baisse la réactivité aux bactéries luminales non invasives contribuerait également à l'incapacité d'éliminer l'infection à $H$. pylori. Les résultats des études de modèles murins sur des vaccins indiquent qu'il faut moduler la réponse des lymphocytes $T$, de lymphocytes $\mathrm{T}$ de type 1 à des lymphocytes $\mathrm{T}$ de type 2 pour prévenir et éliminer l'infection à $H$. pylori. La compréhension des mécanismes par l'entremise desquels la réponse immunitaire contrôle les infections bactériennes permettra la mise au point de nouvelles stratégies d'immunomodulation et le développement d'un vaccin pour le traitement et la prévention des infections à $H$. pylori.
$S^{i}$ nce its identification more than 10 years ago, it has become apparent that Helicobacter pylori is an important pathogen of the upper gastrointestinal tract (1). H pylori is the cause of type B chronic active gastritis and is a factor in the development of over $90 \%$ of duodenal ulcers. Potentially of greater importance is the strong link between $H$ pylori and the development of gastric cancers. The high prevalence of helicobacter infection in the world and its link to these diseases makes this one of the world's leading health problems $(2,3)$. Understanding the pathogenesis of $\mathrm{H}$ pylori-associated diseases is critical for the development of new management strategies to deal with this infection. The present review considers the current understanding of the immunopathogenesis of helicobacter infections and highlights the potential utility of treatments based on modulating the host immune response.

\section{SPECTRUM OF H PYLORI- ASSOCIATED DISEASES}

Infection with $H$ pylori initially leads to an acute gastritis that is soon followed by the development of chronic active gastritis. The infection generally persists for life, with the individual often remaining asymptomatic. Only about onehalf of subjects develop dyspepsia with $\mathrm{H}$ pylori-associated chronic active gastritis, a smaller proportion develop more severe gastric damage with duodenal or gastric ulceration, and an even smaller number have disease complicated by gastric carcinoma, lymphoma or gastric mucosal-associated lymphoid tissue (MALT) lymphoma. The factors that lead to a particular disease outcome are not clear but may relate to either differences in host defense mechanisms or heterogeneity among $H$ pylori strains, or both. 
Many studies have shown that successful eradication of $H$ pylori can cure duodenal ulcer disease (4). H pylori is classified by the International Agency for Research on Cancer as a group I carcinogen (5). Therefore, there may be a theoretical benefit in treating $\mathrm{H}$ pylori infection to prevent gastric cancers. However, no data show that this strategy will, in fact, prevent cancer development $(2,6)$. Therefore, the goal of eliminating $H$ pylori infection is well supported in established peptic ulcer disease but remains controversial in asymptomatic infections. In part, difficulties with a program of widespread treatment of $H$ pylori are the cost and possible side effects of antibiotic treatment, and the variable response to treatment associated with an increasing incidence of antibiotic-resistant strains $(7,8)$. As the arguments to treat all $\mathrm{H}$ pylori-infected patients become more convincing, there is a growing need to explore alternative treatment strategies that can be applied on a large scale.

\section{CHARACTERISTICS OF H PYLORI INFECTION}

$H$ pylori is probably the commonest of all bacterial infections, with a worldwide prevalence of approximately 50\% (9). The organism has adapted to the hostile niche of the human stomach, where it survives in close apposition to gastric epithelial cells. Much has been learned about $H$ pylori with respect to the ability of the organism to colonize the human stomach. H pylori maintains a persisting infection in the stomach despite the accompanying humoral and cell-mediated immune responses $(10,11)$. This suggests that the immune system cannot eliminate or control the infection. On the other hand, a recent study from China showed that once $H$ pylori is eradicated by treatment, infection rarely recurs in adults, even in developing nations (12). This finding suggests that the immune system may be effective in preventing reinfection. Results from animal studies of oral vaccines, discussed below, support this contention. What remains to be determined is what allows the immune response to become effective in dealing with $\mathrm{H}$ pylori infection.

\section{MUCOSAL IMMUNE RESPONSE}

MALT in the small intestine consists of organized lymphoid structures such as Peyer's patches, lymphoid follicles and mesenteric lymph nodes. In addition, the epithelial layer and lamina propria contain immune cells (13). Overlying the Peyer's patches are specialized epithelial cells referred to as 'M-cells', which serve as entry points for foreign antigens (14). Antigens taken up by M cells are transported into the Peyer's patches where the inductive phase of the intestinal immune response occurs. It is there that antigen-specific $B$ cells are stimulated and undergo switching from immunoglobulin (Ig) M- to IgA-producing B cells. These cells leave the Peyer's patches via the lymphatics to enter the thoracic duct, travel to the systemic circulation and selectively return to mucosal sites, particularly the intestine. This recirculation has led to the notion of a 'common mucosal immune system', whereby immunization at one mucosal surface leads to immunity at other mucosal surfaces (15). Although it is reasonable to assume that the gastric mucosa is part of the common mucosal immune system, this speculation remains to be confirmed experimentally. Interestingly, a recent study showed that rectal and intranasal immunization protected against gastric infection with $H$ pylori in the mouse (16). These data provide initial support for a link between the stomach and other mucosal sites.

The normal gastric mucosa is characterized by a paucity of immune cells, a consequence presumably of the fact that a normal stomach maintains a relatively sterile environment. On the other hand, the gastric mucosal lamina propria of patients infected with $\mathrm{H}$ pylori is infiltrated by neutrophils, lymphocytes and plasma cells and, in the epithelium, by intraepithelial lymphocytes (17). As the inflammation increases, lymphoid aggregates and follicles reminiscent of the normal intestine are recognized (18). Although it is tempting to speculate that the inflamed stomach can mount an immune response, several elements of the MALT, such as $\mathrm{M}$ cells, remain absent. It is not clear whether an immune response can be initiated in the gastric mucosa or whether epithelial cells expressing major histocompatibility complex (MHC) class II molecules in the inflamed gastric mucosa function as antigen-presenting cells $(19,20)$. In fact, recent evidence suggests that $\mathrm{H}$ pylori causes epithelial cell apoptosis through direct interactions with MHC class II molecules (21). Therefore, the gastric mucosa of $H$ pylori-infected individuals acquires elements of the immune system and appears to participate in both the afferent and efferent limbs of the immune response to infection.

The ability of the gastric mucosa to contribute to the local immune response is supported by the finding of $\mathrm{H}$ pylorispecific IgA in gastric secretions (22). IgA is the predominant antibody of mucosal surfaces presumably because it survives the hostile environment of the gut lumen (23). In the intestine, local $\mathrm{T}$ cells preferentially drive $\mathrm{B}$ cells towards IgA production through the secretion of cytokines such as interleukin (IL)-4 (24). The mechanisms controlling gastric $\mathrm{T}$ cells and their ability to regulate local IgA production are not well understood. It is evident that immune effector cells accumulate in response to $H$ pylori infection and may initiate and participate in the immune response in the stomach. It should be noted, however, that $H$ pylori occupies a niche that is not easily accessible to the cells and chemical mediators of the local immune response. How the immune system overcomes such a barrier is not known.

Gastric inflammation: The inflammatory infiltrate seen in $\mathrm{H}$ pylori-associated gastritis includes neutrophils and mononuclear cells with plasma cells and lymphocytes. The lymphocytes include both CD4 and CD8 T cells in the lamina propria, and CD8-expressing lymphocytes in the epithelium (25). The precise role that each of these $T$ cell subsets plays in contributing to inflammation is not known. The generation of antigen-specific $\mathrm{B}$ cell responses includes the production of IgG and IgA antibodies. IgG is a potent activator of complement, which may contribute to inflammation and local tissue damage. In addition, there is evidence that autoantibodies develop in association with $\mathrm{H}$ pylori-associated gastritis that may contribute to mucosal damage (26). 
Helper T cells have been divided into T helper cell type (Th) 1 and Th2 subtypes based on the profile of cytokines that they produce. Th1 cells produce IL-2, tumour necrosis factor-alpha (TNF- $\alpha$ ) and interferon-gamma (IFN- $\gamma$ ) and contribute to cell-mediated immunity. Th2 cells, on the other hand, secrete IL-4, IL-5, IL-6 and IL-10, which contribute to $\operatorname{Ig} \mathrm{A}$ and $\operatorname{IgE}$ antibody responses and stimulate eosinophilia and mast cell hyperplasia (27). This model provides the framework for the analysis of cytokine responses to infectious pathogens. It has been suggested that Th1 response to H pylori infections is deleterious because it can induce mucosal inflammation and tissue damage, whereas $\mathrm{Th} 2$ response is more effective in eliminating the organism through the induction of protective antibody responses (discussed in more detail below, see Figure 1). For example, TNF- $\alpha$ has cytotoxic effects on intestinal epithelial cells, and IFN- $\gamma$ contributes to mucosal damage as a consequence of local $\mathrm{T}$ cell activation (28). On the other hand, IL-4 can damage the gastric mucosa when given intravenously to humans (29). In situ studies indicate that both TNF- $\alpha$ and IFN- $\gamma$ production increase in $H$ pylori-induced gastritis, supporting a local Th1 type response $(30,31)$; however, the degree to which gastric $\mathrm{T}$ lymphocyte responses are predominately Th1 or Th2 type remains the subject of intensive investigation.

In addition to lymphocytes, epithelial cells and possibly other structural cells of the gastric mucosa can produce cytokines. In $\mathrm{H}$ pylori-infected gastric tissues, increases in the proinflammatory cytokines IL- 6 and IL- 8 have been found. These cytokines can be produced by gastric epithelial cells and serve to amplify the local inflammatory response $(32,33)$. Activation of $\mathrm{T}$ cells can affect normal physiological functions in the intestine $(34,35)$. In the stomach, similar interactions may occur, with early evidence suggesting that this results in alterations in acid secretion $(36,37)$.

\section{BACTERIAL INFLUENCES ON THE HOST RESPONSE}

Bacterial-derived factors also influence the inflammatory and immune responses to $H$ pylori infection. Interactions between bacteria and epithelial cells can lead to the induction of surface molecules such as MHC class II molecules on epithelial cells and the production of chemokines, including IL-8 (33), TNF- $\alpha$, tumour growth factor-beta and IL-6 $(38,39)$. Such interactions may influence the Th1/Th2 balance. Recent work has identified genes that contribute to the pathogenetic ability of the organism, including picB/cagE, which produces a factor that directly increases IL- 8 production by epithelial cells (40).

\section{ANIMAL MODELS}

Animal models are critical to the study of immune responses to infectious agents. Helicobacter felis infects the mouse stomach and leads to significant chronic inflammation (41-43). The inflammatory infiltrate can evolve into lymphoid follicles containing IgM-positive and IgA-positive B cells and CD4-positive T cells $(44,45)$. From studies in mice, it is ap-

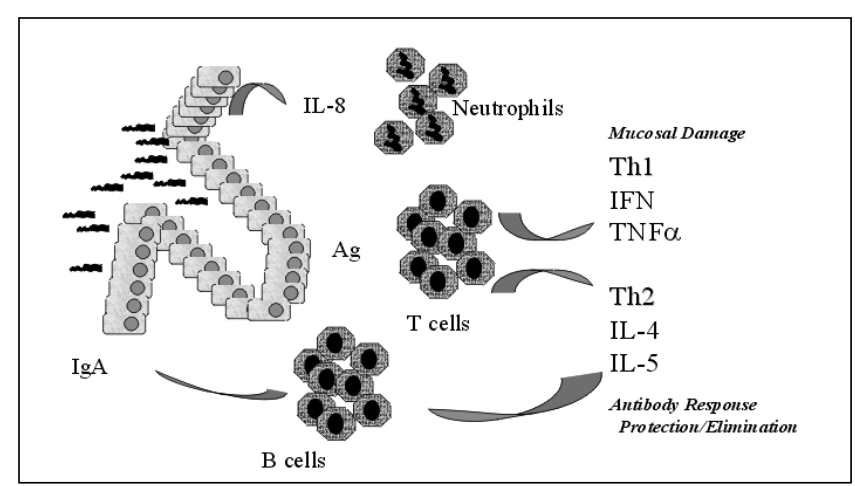

Figure 1) Schematic diagram of the host immune response to helicobacter infection. Helicobacter pylori can activate epithelial cells to secrete chemokines that influence neutrophil chemotaxis and recruitment to the mucosa. T cells and B cells are stimulated by antigen $(\mathrm{Ag})$, although it is not clear whether gastric epithelial cells expressing major histocompatibility complex class II antigen can present antigen directly to T cells. Nonetheless, mucosal T cells are shown producing T helper cell (Th) type 1 or Th2 cytokines. Th2 cytokines promote protection and eradication of infection through their influence on antibody production by local B cells. On the other hand, it has been suggested that Th1 responses promote mucosal damage and do not contribute to eradication. IFN Interferon; Ig Immunoglobulin; IL Interleukin; TNF $\alpha$ Tumour necrosis factor-alpha

parent that IgA responses are protective (46) but not absolutely required for the success of oral vaccines (47).

The cellular immune response to $H$ felis infection in the mouse has been more difficult to define. One study showed a helicobacter-independent response directed against urease and heat shock proteins, and a helicobacter-specific response characterized by the production of IFN $-\gamma$ with little IL-4 production (48). Treating mice with the neutralizing anti-IFN- $\gamma$ antibody diminished the inflammatory changes, suggesting that IFN- $\gamma$ contributed to mucosal damage.

Role of the host in helicobacter-induced immune response: Studies of peptic ulcer disease antedating the identification of $\mathrm{H}$ pylori suggested a strong genetic component to the development of ulcer diseases (49). This issue should be reexamined. Immune competence of the host may influence $H$ pylori-induced gastritis. For example, patients infected with the human immunodeficiency virus have a decreased prevalence of $H$ pylori infection that is not related to the concurrent use of antibiotics (50). H felis infection of severe combined immunodeficient mice, however, leads to a gastritis that is similar to that seen in immunocompetent strains (51). Therefore, the manner in which the immunocompetence of the host influences the outcome of helicobacter infection is complex. The genetic background of immunocompetent mice also influences the response to $\mathrm{H}$ felis infection (52). Balb/c mice develop less intense gastric inflammation than $\mathrm{C} 57 \mathrm{Bl} / 6$ (B6) mice. One explanation for this is that Balb/c mice tend to secrete Th2 type cytokines (increased IL-4, IL-5) in response to microbial infections, while B6 mice secrete Th1 cytokines (IFN- $\gamma$ ) (53) (Table 1). Interestingly, treating B6 mice with anti-IFN $-\gamma$ does not alter the severity of the $\mathrm{H}$ felis infection (48). How the genetic background of humans influ- 
TABLE 1 Degree of helicobacter colonization and gastritis compared
with susceptibility to other bacterial infections in different
strains of mice

\begin{tabular}{lccc}
\hline & \multicolumn{3}{c}{ Mouse strain } \\
Type of infection & Balb/c & C3H & C57BL/6 \\
\hline Helicobacter felis colonization & Moderate & Low & High \\
H felis-associated gastritis & Low & High & High \\
Leishmania species & $\mathrm{S}$ & $\mathrm{S}$ & $\mathrm{R}$ \\
Salmonella species & $\mathrm{S}$ & $\mathrm{R}$ & $\mathrm{S}$ \\
Listeria species & $\mathrm{S}$ & - & $\mathrm{R}$ \\
Yersinia species & $\mathrm{S}$ & - & $\mathrm{R}$ \\
\hline
\end{tabular}

R Resistant; S Susceptible

ences the response to $H$ pylori infection is not known and should become the subject of investigative efforts.

Vaccines and immune protection: In the intestine, mechanisms have evolved to regulate the mucosal immune response and to prevent chronic inflammatory damage. Oral immunization leads to specific immune tolerance (54). The mechanisms for this are still not well understood, but it is evident that $T$ cells in the intestinal mucosa are unique in phenotype and function compared with $T$ cells in the blood (55). This heterogeneity is related in part to the mucosal microenvironment, the gut flora and their effects on $\mathrm{T}$ cell differentiation and repertoire selection. How gastric $T$ cells compare with intestinal $\mathrm{T}$ cells in these respects remains to be evaluated. Overcoming oral tolerance remains a major obstacle to the design of oral vaccines, and oral tolerance may well explain how $H$ pylori evades immune-mediated elimination.

$\mathrm{H}$ pylori-specific cellular immune responses in humans are not well understood. Immunohistochemical studies indicate that changes occur in $\mathrm{T}$ cell subsets in both the lamina propria and the epithelium. Several groups have suggested that $H$ pylori-positive patients have a diminished cellular response to $H$ pylori antigen $(56,57)$. This may be due to organism-specific responses at the clonal level being masked by nonspecific proliferative responses to whole bacteria. More information is emerging as new techniques such as intracellular cytokine detection by flow cytometry and quantitative polymerase chain reaction are being used to address these issues.

Animal studies indicate that helicobacter vaccines given with the mucosal adjuvant cholera toxin not only protect against $\mathrm{H}$ felis but also eliminate established infections (58-60). Thus, appropriate stimulation of the immune response in the gastric mucosa can lead to elimination of the infection. The requirement for a mucosal adjuvant such as cholera toxin or heat-labile enterotoxin of Escherichia coli suggests that immune modulation is needed to overcome the tendency towards oral tolerance $(46,61)$. These adjuvants stimulate secretory IgA and local cellular responses and preferentially stimulate Th2-type responses with IL-4 and IL-10 production. Therefore, it has been suggested that therapeutic strategies modulating the mucosal immune response towards a Th2 response would prove beneficial in the treatment of established infection. In a recent study by Mohammadi et al (62), mice infected with $H$ felis and injected with Th2 cell lines showed a decrease in the degree of $\mathrm{H}$ felis gastric colonization. This intriguing study suggests that modulating the immune response towards a Th2predomint response may indeed be the means by which vaccines lead to $H$ felis eradication. The issue of potential toxicity of mucosal adjuvant use in humans needs to be addressed (61), and the direct role of Th1 cytokines in helicobacter infection needs to be explored.

\section{CONCLUSIONS}

Helicobacter infection is an enigma because the infection persists in the face of an apparent vigorous immune response and an associated inflammatory response. On the other hand, in animal models, oral vaccination together with mucosal adjuvants not only prevents infection but is also effective in eliminating established infection. Understanding the factors that alter the immune response, rendering it effective in the prevention or elimination of helicobacter infection, is critical to the design of future treatment strategies. These issues await advancements in the understanding of the pathophysiological alterations that occur in patients with $H$ pylori-mediated gastric diseases.

\section{REFERENCES}

1. Marshall BJ, Warren JR. Unidentified curved bacillus on gastric epithelium in the stomach of patients with gastritis and peptic ulceration. Lancet 1984;i:1311-5.

2. Parsonnet J, Friedman GD, Vandersteen DP, et al. Helicobacter pylori infection and the risk of gastric carcinoma. N Engl J Med 1991;325:1127-31.

3. Bardhan PK. Epidemiological features of Helicobacter pylori infection in developing countries. Clin Infect Dis 1997;25:973-8.

4. O'Brien B, Goeree R, Mohamed AH, Hunt R. Cost-effectiveness of Helicobacter pylori eradication for the long-term management of duodenal ulcer in Canada. Arch Intern Med 1995;155:1958-64.

5. Forman D. Essential co-factors in gastric carcinogenesis. In: Hunt RH, Tytgat GNJ, eds. Helicobacter pylori. Basic Mechanisms to Clinical Cure 1996. Dordrecht: Kluwer Academic Publishers, 1996:255-61.

6. Graham DY. Can therapy ever be denied for Helicobacter pylori infection? Gastroenterology 1997;113:S113-7.

7. Fennerty MB. What are the treatment goals for Helicobacter pylori infection? Gastroenterology 1997;113:S120-5.

8. Lee J, O'Morain C. Who should be treated for Helicobacter pylori infection? A review of consensus conferences and guidelines. Gastroenterology 1997;113:S99-106.

9. Marshall BJ. Helicobacter pylori in peptic ulcer: Have Koch's postulates been fulfilled? Ann Med 1995;27:565-8.

10. Croitoru K, Hunt R. Immunopathologie des infections a Helicobacter. In: Mege JL, Raoult D, Revillard JP, eds. Immunite et Infection: Concepts immunopathologiques et perspectives therapeutiques. Paris: Arnette, 1997:387-95.

11. Croitoru K, Snider DP. What determines the vigour of the immune response to Helicobacter pylori? In: Hunt RH, Tytgat GNJ, eds. Helicobacter pylori. Basic Mechanisms to Clinical Cure 1996. Dordrecht: Kluwer Academic Publishers, 1996:158-67.

12. Mitchell HM, Hu P, Chi Y, Chen MH, Li YY, Hazell SL. A low rate of reinfection following effective therapy against Helicobacter pylori in a developing nation (China). Gastroenterology 1998;114:256-61.

13. Croitoru K, Bienenstock J. Characteristics and functions of mucosa-associated lymphoid tissue. In: Ogra PL, Strober W, Mestecky J, McGhee JR, Lamm ME, Bienenstock J, eds. Handbook of Mucosal Immunology. San Diego: Academic Press, 1994:141-9.

14. Owen RL, Jones AL. Epithelial cell specialization within human Peyer's patches: an ultrastructural study of intestinal lymphoid follicles. Gastroenterology 1974;66:189-203.

15. Bienenstock J, McDermott M, Befus D, O’Neill M. A common 
mucosal immunologic system involving the bronchus, breast and bowel. Adv Exp Med Biol 1978;107:53-9.

16. Kleanthous H, Myers GA, Georgakopoulos KM, et al. Rectal and intranasal immunizations with recombinant urease induce distinct local and serum immune responses in mice and protect against Helicobacter pylori infection. Infect Immun 1998;66:2879-86.

17. Trejdosiewicz LK, Calabrese A, Smart CJ, et al. Gamma/ $\delta$ T cell receptor-positive cells of the human gastrointestinal mucosa: Occurrence and V region gene expression in Helicobacter pyloriassociated gastritis, coeliac disease and inflammatory bowel disease. Clin Exp Immunol 1991;84:440-4.

18. Genta RM, Hamner HW, Graham DY. Gastric lymphoid follicles in Helicobacter pylori infection: Frequency, distribution, and response to triple therapy. Hum Pathol 1993;24:577-83.

19. Bland PW, Kambarage DM. Antigen handling by the epithelium and lamina propria macrophages. Gastroenterol Clin North Am 1991;20:577-96.

20. Papadimitrou CS, Ioachim-Velogianni EE, Tsianos EB, Moutsopoulos HM. Epithelial HLA-DR expression and lymphocyte subsets in gastric mucosa in type B chronic gastritis. Virchows Arch A Pathol Anat Histopathol 1988;413:197-204.

21. Fan XJ, Crowe SE, Behar S, et al. The effect of class II major histocompatibility complex expression on adherence of Helicobacter pylori and induction of apoptosis in gastric epithelial cells: A mechanism for T helper cell type 1-mediated damage. J Exp Med 1998;187:1659-69.

22. Sobala GM, Crabtree JE, Dixon MF, et al. Acute Helicobacter pylori infection: clinical features, local and systemic immune response, gastric mucosal histology, and gastric juice ascorbic acid concentrations. Gut 1991;32:1415-8.

23. Hanson LA, Brandtzaeg P. The discovery of secretory $\operatorname{Ig} A$ and the mucosal immune system. Immunol Today 1993;14:416-7.

24. Vajdy M, Koscos-Vilbois MH, Kopf M, Kohler G, Lycke N. Impaired mucosal immune responses in interleukin 4-targeted mice. J Exp Med 1995;181:41-53.

25. Valnes K, Huitfeldt HS, Brandtzaeg P. Relation between T cell number and epithelial HLA class II expression quantified by image analysis in normal and inflamed human gastric mucosa. Gut 1990;31:647-52.

26. Negrini R, Lisato L, Zanella I, et al. Helicobacter pylori infection induces antibodies cross-reacting with human gastric mucosa. Gastroenterology 1991;101:437-45.

27. Mosmann TR, Coffman RL. Heterogeneity of cytokine secretion patterns and functions of helper T cells. Adv Immunol 1989;46:111-47.

28. Targan SR, Deem RL, Shanahan F. Role of mucosal T-cell-generated cytokines in epithelial cell injury. Immunol Res 1991;10:472-8.

29. Rubin JT, Lotze MT. Acute gastric mucosal injury associated with the systemic administration of interleukin-4. Surgery 1992;111:274-80.

30. Karttunen R, Karttunen T, Ekre HP, MacDonald TT. Interferon gamma and interleukin 4 secreting cells in the gastric antrum in Helicobacter pylori positive and negative gastritis. Gut 1995;36:341-5.

31. Bamford KB, Fan XJ, Crowe SE, et al. Lymphocytes in the human gastric mucosa during Helicobacter pylori have a T helper cell 1 phenotype. Gastroenterology 1998;114:482-92.

32. Crabtree JE, Farmery SM, Lindley IJD, Figura N, Peichl P, Tompkins DS. CagA/cytotoxic strains of Helicobacter pylori and interleukin-8 in gastric epithelial cell lines. J Clin Pathol 1994;47:945-50.

33. Crowe SE, Alvarez L, Dytoc M, et al. Expression of interleukin 8 and CD54 by human gastric epithelium after Helicobacter pylori infection in vitro. Gastroenterology 1995;108:65-74.

34. McKay DM, Croitoru K, Perdue MH. T cell-monocyte interactions regulate epithelial physiology in a coculture model of inflammation. Am J Physiol 1996;270:C418-28.

35. McKay DM, Benjamin M, Baca-Estrada M, D'Inca R, Croitoru K, Perdue MH. Role of $\mathrm{T}$ lymphocytes in secretory response to an enteric nematode parasite: Studies in athymic rats. Dig Dis Sci 1995;40:331-7.

36. Collins SM, Croitoru K. The pathophysiology of inflammatory bowel disease: The effect of inflammation on intestinal function. In: Targan S, Shanahan F, eds. Inflammatory Bowel Disease: From Bench to Bedside. Baltimore: Williams \& Wilkins, 1993:194-209.

37. Muller MJ, Padol I, Ernst PB, Croitoru K, Hunt RH. Interferongamma inhibits secretagogue-mediated acid secretion in isolated murine gastric glands. Gastroenterology 1993;104:A151. (Abst)
38. Crabtree JE, Shallcross TM, Heatley RV, Wyatt JI. Mucosal tumour necrosis factor $\alpha$ and interleukin-6 in patients with Helicobacter pylori associated gastritis. Gut 1991;32:1473-7.

39. Fan X-G, Chua A, Fan X-J, et al. Increased gastric production of interleukin-8 and tumour necrosis factor in patients with Helicobacter pylori infection. J Clin Pathol 1995;48:133-6.

40. Tummuru MKR, Sharma SA, Blaser MJ. Helicobacter pylori picB, a homologue of the Bordetella pertussis toxin secretion protein, is required for induction of IL-8 in gastric epithelial cells. Mol Microbiol 1995; 18:867-76.

41. Karita M, Kouchiyama T, Okita K, Nakzawa T. New small animal model of human gastric Helicobacter pylori infection: Success in both nude and euthymic mice. Am J Gastroenterol 1991;86:1596-603.

42. Michetti P, Corthésy-Theulaz I, Davin C, et al. Immunization of $\mathrm{BALB} / \mathrm{c}$ mice against Helicobacter felis infection with Helicobacter pylori urease. Gastroenterology 1994;107:1002-11.

43. Enno A, O'Rourke JL, Howlett CR, Jack A, Dixon MF, Lee A. MALToma-like lesions in the murine gastric mucosa after long-term infection with Helicobacter felis: A mouse model of Helicobacter pylori-induced gastric lymphoma. Am J Pathol 1995;147:217-22.

44. Lee A, Fox JG, Otto G, Murphy J. A small animal model of human Helicobacter pylori active chronic gastritis. Gastroenterology 1990;99:1315-23.

45. Fox JG, Blanco M, Murphy JC, et al. Local and systemic immune responses in murine Helicobacter felis active chronic gastritis. Infect Immun 1993;61:2309-15.

46. Lee CK, Weltzin R, Thomas WD Jr, et al. Oral immunization with recombinant Helicobacter pylori urease induces secretory $\operatorname{IgA}$ antibodies and protects mice from challenge with Helicobacter felis. J Infect Dis 1995;172:161-72.

47. Bogstedt AK, Nava S, Wadström T, Hammarström L. Helicobacter pylori infections in IgA deficiency: Lack of role for the secretory immune system. Clin Exp Immunol 1996;105:202-4.

48. Morris A, Nicholson G. Ingestion of Campylobacter pyloridis causes gastritis and raised fasting gastric $\mathrm{pH}$. Am J Gastroenterol 1987;82:192-9.

49. Rotter JI, Sones JQ, Samloff IM, et al. Duodenal-ulcer disease associated with elevated serum pepsinogen I: an inherited autosomal dominant disorder. N Engl J Med 1979;300:63-6.

50. Blecker U, Keymolen K, Levy J, Vandenplas Y. Low prevalence of Helicobacter pylori in the acquired immunodeficiency syndrome. Am J Gastroenterol 1993;88:1294. (Lett)

51. Blanchard TG, Czinn SJ, Nedrud JG, Redline RW. Helicobacter-associated gastritis in SCID mice. Infect Immun 1995;63:1113-5.

52. Marshall BJ, Armstrong JA, McGechie DB. Attempt to fulfill Koch's postulate for pyloric Campylobacter. Med J Aust 1985;142:436-9.

53. Finkelman FD, Pearce EJ, Urban JF, Sher A. Regulation and biological function of helminth-induced cytokine response. Immunol Today 1991;12:A62-6.

54. Brandtzaeg P. History of oral tolerance and mucosal immunity. Ann NY Acad Sci 1996;778:1-27.

55. Croitoru K, Ernst PB. Leukocytes in the intestinal epithelium: An unusual immunological compartment revisited. Regional Immunol 1992;4:63-9.

56. Tosi MF, Sorensen RU, Czinn SJ. Cell-mediated immune responsiveness to Helicobacter pylori in healthy seropositive and seronegative adults. Immunol Infect Dis 1992;2:133-6.

57. Fan XJ, Chua A, Shahi CN, McDevitt J, Keeling PW, Kelleher D. Gastric T lymphocyte responses to Helicobacter pylori in patients with H pylori colonization. Gut 1994;35:1379-84.

58. Czinn SJ, Nedrud JG. Oral immunization against Helicobacter pylori. Infect Immun 1991;59:2359-63.

59. Corthésy-Theulaz I, Porta N, Glauser M, et al. Oral immunization with Helicobacter pylori urease B subunit as a treatment against Helicobacter infection in mice. Gastroenterology 1995;109:115-21.

60. Cuenca R, Blanchard TG, Czinn SJ, et al. Therapeutic immunization against Helicobacter mustelae in naturally infected ferrets. Gastroenterology 1996;110:1770-5.

61. Snider DP. The mucosal adjuvant activities of ADP-ribosylating bacterial enterotoxins. Crit Rev Immunol 1995;15:317-48.

62. Mohammadi M, Nedrud J, Redline R, Lycke N, Czinn SJ. Murine CD4 T-cell response to Helicobacter infection: TH1 cells enhance gastritis and TH2 cells reduce bacterial load. Gastroenterology 1997;113:1848-57. 


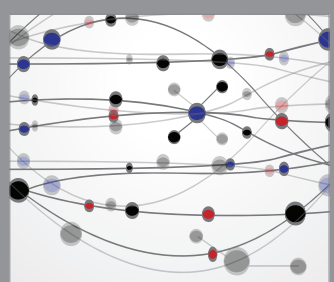

The Scientific World Journal
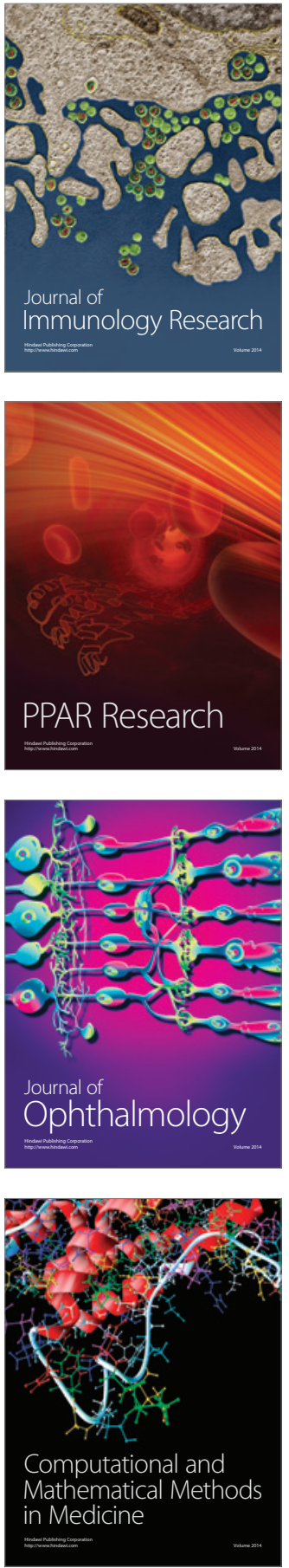

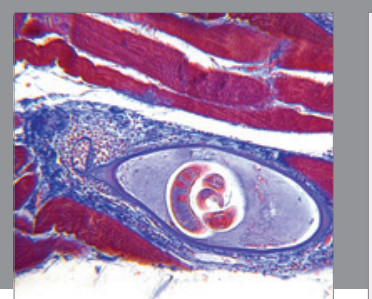

Gastroenterology Research and Practice

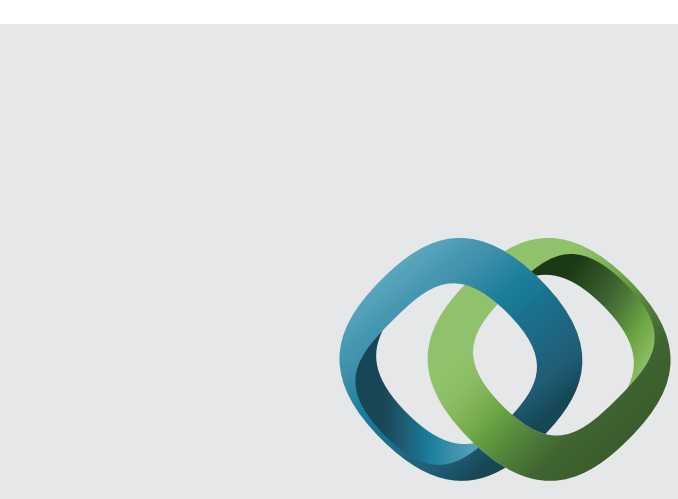

\section{Hindawi}

Submit your manuscripts at

http://www.hindawi.com
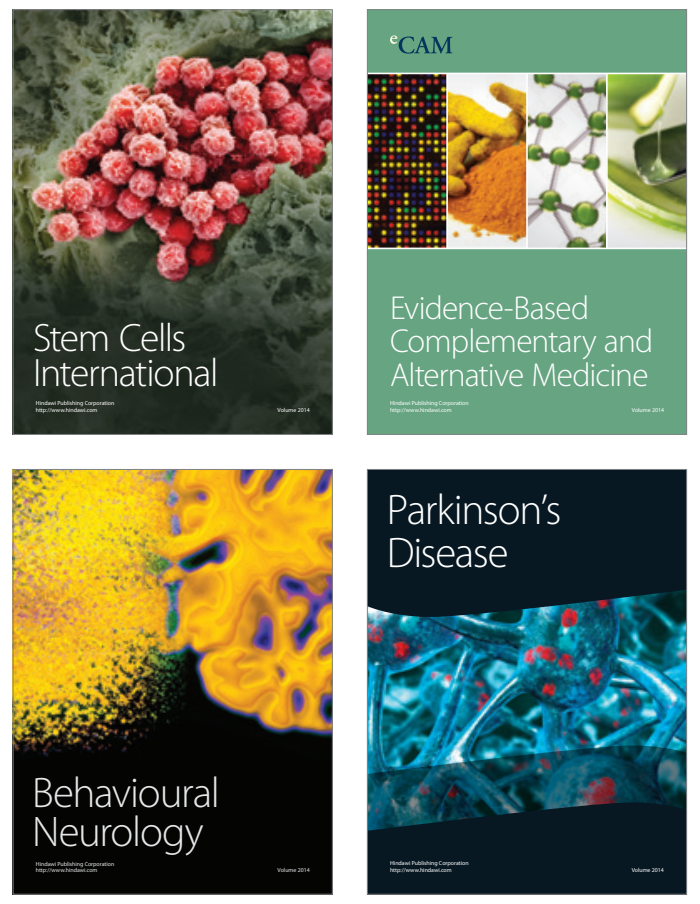
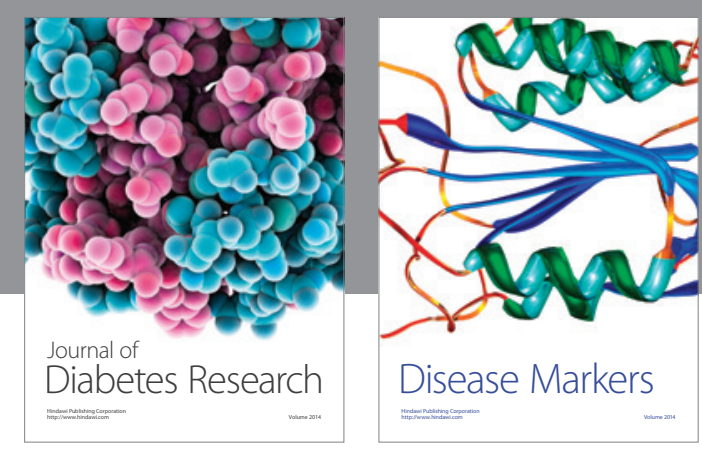

Disease Markers
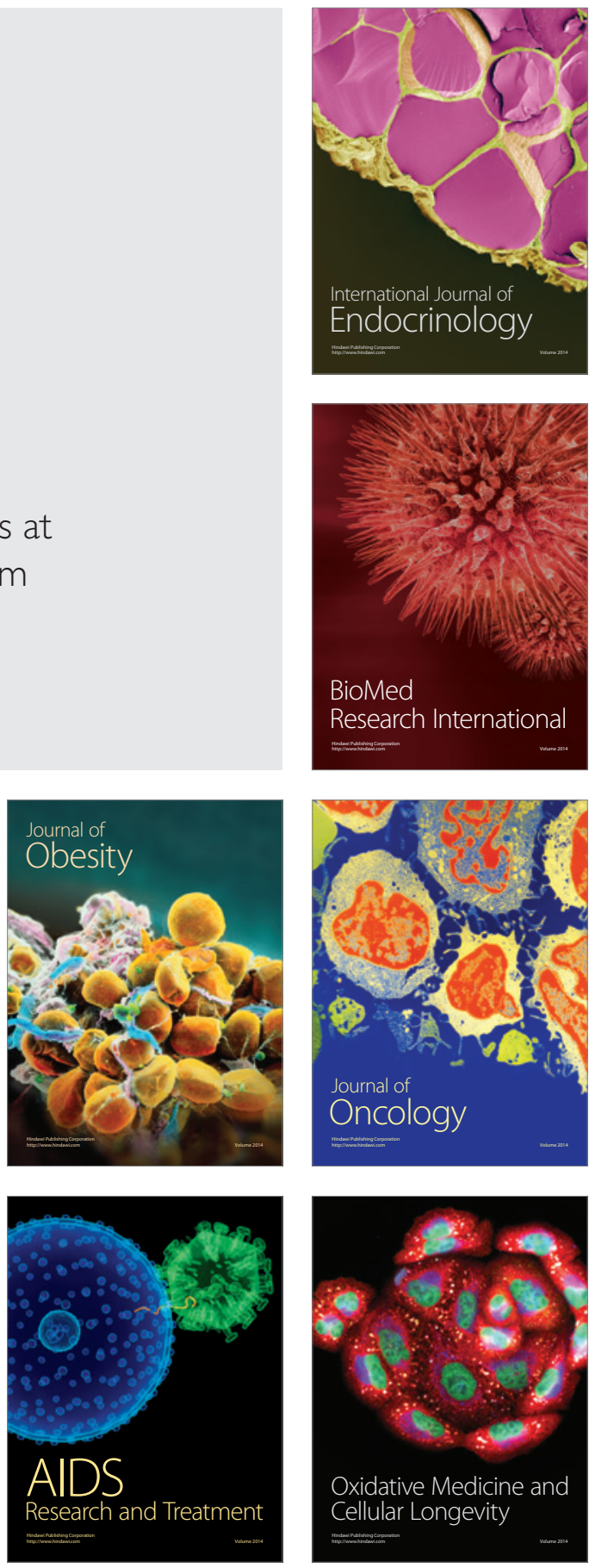